\title{
The longhorn beetles (Coleptera Cerambycidae) of Mardin province (Turkey) with the description of two new species and one new subspecies
}

\author{
Pierpaolo Rapuzzi ${ }^{*}$, Gianfranco Sama ${ }^{2}$, Sadreddin Tusun ${ }^{3}$, Hüseyin Cebeci', Hüseyin Özdikmen 5 , Daniele \\ Baiocchi' ${ }^{6}$, Gianluca Magnani ${ }^{7}$, Ivan Rapuzzi' \& Musa Geçit ${ }^{8}$ \\ ${ }^{1}$ Via Cialla 48, 33040 Prepotto (UD), Italy WBA member. e-mail: info@ronchidicialla.it \\ ${ }^{2}$ Via Raffaello 84, 47023 Cesena (FC), Italy. e-mail: francosama@gmail.com \\ ${ }^{3}$ Dicle University, Ziya Gökalp Education Faculty, Biology Department, 21280, Diyarbakır, Turkey. e-mail: sadred- \\ din.tusun@dicle.edu.tr \\ ${ }^{4}$ Istanbul University-Cerrahpasa, Faculty of Forestry, Istanbul, Turkey. e-mail: hcebeci@istanbul.edu.tr \\ ${ }^{5}$ Department of Biology, Faculty of Science, Gazi University, 06500 Ankara, Turkey; e- mail: ozdikmen@gazi.edu.tr \\ ${ }^{6}$ Via Matteo Babini 26, 00139 Roma, Italy, WBA member. e-mail: danielbai@tin.it \\ ${ }^{7}$ Via Gianfanti 6, 47521 Cesena (FC), Italy, WBA member. e-mail: magnanig@tiscali.it \\ ${ }^{8}$ Nur Mah. Kamu Cad. Buluş Apt. Sitesi A Blok No:10 İç Kap1 No:11 Artuklu/Mardin, Turkey; e-mail: \\ musagecitii@gmail.com \\ ${ }^{*}$ Corresponding author
}

\begin{abstract}
In this paper we provide a check-list of the Coleoptera Cerambycidae of Mardin province (Southeastern Turkey); describe two new species, Agapanthia mardinensis Rapuzzi n. sp. and Pygoptosia darzerkensis Rapuzzi n. sp. and one new subspecies, Phytoecia (Neomusaria) mesopotamica barbarae Rapuzzi n. ssp. Additionally, three species and one subspecies are recorded for the first time for the Turkish Fauna. Information obtained from literature is listed, as well as the results of researches conducted in the area by the authors during several entomological expeditions. Additional data of specimens preserved in several European Museums is given.
\end{abstract}

ÖZET Bu çalışmada, Mardin ilinin Coleoptera Cerambycidae familyasının tür listesi verilmiş olup, iki yeni tür (Agapanthia mardinensis Rapuzzi n. sp. ve Pygoptosia darzerkensis Rapuzzi n. sp.) ve bir yeni alttür (Phytoecia (Neomusaria) mesopotamica barbarae Rapuzzi n. ssp.) tanımlanmıştır. Ayrıca, ilk olarak Türk faunasında üç tür ve bir alttür kaydedilmiştir. Elde edilen tüm bilgiler listelenen literatürlerden ve araştırıcıların arazi çalışmalarından elde edilmiştir. Avrupa' daki bazı müzelerde korunan örneklere ait ilave veriler de metin içerisinde sunulmaktadır.

KEY WORDS Cerambycidae; new species; new subspecies; new records; fauna; Turkey; Mardin.

Received 26.05.2021; accepted 28.06.2021; published online 24.07.2021

\section{INTRODUCTION}

The cerambycid fauna of Mardin turned out to be very interesting and this paper shows how poorly known it has been so far. In fact, only 45 species were known in the literature up to now, while after research carried out by the authors of the present study, that total has been increased to 77 species. 
Five species are deleted from the original list due to misidentification (Pedostrangalia (Neosphenalia) emmipoda (Mulsant, 1863); Purpuricenus dalmatinus Sturm, 1843; Dorcdion (Cribridorcadion) delagrangei Pic, 1894; Dorcadion (Cribridorcadion) hellmanni Ganglbauer, 1884; Phytoecia (Helladia) pretiosa Faldermann, 1837), while 2 new species (Agapanthia mardinensis Rapuzzi sp. nov. and Pygoptosia darzerkensis Rapuzzi sp. nov.) and one new subspecies (Phytoecia (Neomusaria) mesopotamica barbarae Rapuzzi ssp. nov.) were discovered and are described below. In addition, three species and one subspecies are recorded for the first time for the Turkish fauna: Trichoferus ivoi Kadlec, 2005; Phytoecia (s. str.) aenigmatica Sama, Rapuzzi \& Rejzek, 2007 and Phytoecia (s. str.) centaureae Sama \& Rapuzzi, 2006; Vadonia unipunctata syricola Holzschuh, 1993.

\section{MATERIAL AND METHODS}

\section{Study area}

The studied area is located in the southeastern part of Turkey. It corresponds to the region of Mardin province and includes ten counties (Mardin, Dargeçit, Derik, Kızıltepe, Mazıdağı, Midyat, Nusaybin, Ömerli, Yeşilli, and Savur), covering an area of ca. 889 square kilometers between $36^{\circ} 55^{\prime}$ and $38^{\circ} 51^{\prime}$ 'North, and $39^{\circ} 56^{\prime}$ and $42^{\circ} 54^{\prime}$ 'East. It borders with the regions of Şanlıurfa, Diyarbakır, Batman, Siirt and Şırnak, as well as with Syria to the south. The area is located in the middle of the two most important rivers in Mesopotamia, the Euphrates (Firat) on the western side and the Tigris (Dicle) on the eastern side. About $5 \%$ of this land, in the north, is covered by mountains that range from east to west, with an average altitude of 1,000 meters, while in the plains areas it ranges around 600 meters. The area's central orography is mainly represented by a plateau with hills and small valleys, with a typical bushy oak cover, along with many vegetable gardens and cultivated fields. In general, territory conditions are rather dry, though several flowing streams occur there (Gümüş Çay1, Çağ-çağ suyu, Savur Çayı etc.). The true Mardin area shows a typical continental climate, while other parts of its region have different microclimatic conditions with both continental and mediterranean features.

\section{Methods}

The present study was carried out in the period of March-October, from 2017 to 2019, in the central districts of Mardin province and Savur district. A total of 120 different localities were investigated, and samples were collected in 86 of these localities. The unidentified specimens were then taken to laboratory in vials containing a solution of $70 \%$ alcohol. The binocular microscope used for study the insects was a Wild M3, with magnifications 10x6, $10 \times 16$ and $10 \times 40$.

The systematic order used is the same used in the Catalogue of the Palearctic Cerambycidae (Löbl and Smetana, 2010) and its most recent update (Danilevsky, 2019). The only difference is that, when the genus is composed by more than one subgenus, we've listed before the species belonging to the nominal subgenus.

The pictures of prepared specimens were taken with a digital camera Olympus Stylus Tough TG4, with an optical zoom 4.5-18.0 mm., 1:2.0-4.9; images of species in nature were taken with a Canon 60D camera with optical zoom 18-135 mm. before their capture.

Data of non-typical specimens are reported verbatim; for what concerns data of type specimens, in order to represent the correct spelling, handwriting, color and order of the lines, pictures of the original labelling are figured at the end of the text.

In order to obtain freshly emerged larvae, woodsamples were collected in the field and taken to laboratory; these samples were kept at room temperature until emergence. For this reason, the date of emergenge in artificial conditions may not correspond to the actual collection period in nature.

The abbreviations of geographical divisions are same as in the Catalogue by Lobl \& Smetana (2010), but Transcaucasian republics (Armenia, Azerbaijan and Georgia) are returned to Asia (Danilevsky, 2019).

Specimens cited in this paper belong to the following public and private collections: GSCC: Gianfranco Sama Private Collection, Cesena (FC), Italy. MCLF: Centre de Conservation et d'Étude des Collections, Lyon, France. MGPA: Photographic archive of Musa Geçit, Mardin, Turkey. NMBS: National History Museum Basel, Switzerland. NMPC: National History Museum Praha, Czech Republic. PRCU: Pierpaolo Rapuzzi Private Collection, Cialla di Prepotto (UD), Italy. 


\section{RESULTS}

PRIONINAE Latreille, 1802

Prionii Latreille, 1802

PRIONINI Latreille, 1802

Prioniens, Prionii Latreille, 1802

Type genus: Prionus Geoffroy, 1762

Mesoprionus Jakovlev, 1887

Prionus (Mesoprionus) Jakovlev, 1887. Type species: Prionus asiaticus Faldermann, 1837.

Mesoprionus persicus (Redtenbacher, 1850)

Prionus persicus Redtenbacher, 1850. Type locality: Südpersien (South Iran).

RANGe. A: IN IQ TR (Danilevsky, 2019).

MARDIN. Artuklu, Nur Mahallesi (Darzerke), 940 m., 20.VI.2016 M. Geçit leg.; Hamzabey Mahallesi (Vadi Birkitılcemel), 976 m., 01.VII.2017, M. Geçit leg. (MGPA).

REMPHANINI Lacordaire, 1868

Remphanides Lacordaire, 1868

Type genus: Remphan Waterhouse, 1835.

Rhaesus Motschulsky 1875

Rhaesus Motschulsky, 1875. Type species: R. persicus Motschulsky, 1875 (= Prionus serricollis Motschulsky, 1838).

Rhaesus serricollis (Motschulsky 1838)

Prionus serricollis Motschulsky, 1838. Type locality: Georgia: Sabin vill. (Kakhetia).

RANGE. E: AL BU GR MC ST TR YU N: EGi A: AB AR CY GG IN IS LE SY TR (Danilevsky, 2019).

Mardin. Artuklu, Hamzabey Mahallesi (Vadi Birkitılcemel), 1020 m., in pupal cell on Juglans sp., 31.VII.2017, M. Geçit leg. (MGPA).

LEPTURINAE Latreille, 1802

Lepturetae Latreille, 1802

LEPTURINI Latreille, 1802

Lepturetae Latreille, 1802

Type genus: Leptura Linnaeus, 1758.
Pedostrangalia Sokolov, 1897

Pedostrangalia Sokolov, 1897. Type species: Pedostrangalia kassjanovi Sokolov, 1897 (= L. imberbis Ménétriés, 1832)

Pedostrangalia (Neosphenalia) Löbl, 2010

Pedostrangalia (Neosphenalia) Löbl, 2010. New name for Sphenalia Daniel, 1904.

Type species: Leptura verticalis Germar, 1822 (Original designation).

Pedostrangala (Neosphenalia) kurda Sama 1996 Pedostrangalia (Sphenalia) kurda Sama, 1996. Type locality: Tunceli, Pülümür; Bitlis, Yolbilen (Turkey); Kurdistan: Mishaw (Irak).

RANGE. A: AR GG IN IQ TR (Danilevsky, 2019).

MARDIN. Haberli (1020 m) $33 \mathrm{~km}$ south-east of Midyat, 17. and 19.V.2001, leg. M. Rejzek; Hop pass, 6.VI.1998, leg. Halada (Sama, Rapuzzi \& Özdikmen, 2012); Mardin (Özdikmen, 2013b: 72); Hop Gecidi, Mardin env., 11-14.5.2005, leg. Orszuli (Coll. S. Kadlec NMPC); Artuklu, Nur Mahallesi, 18.V.2016, M. Geçit leg.; Hamzabey Mahallesi, 900 m., 24.V.2017, on flowers of Malabaila secacul and Paliurus spina-christi, M. Geçit leg. (MGPA).

[Pedostrangalia (Neosphenalia) emmipoda (Mulsant, 1863)]

Leptura emmipoda Mulsant, 1863. Type locality: "La Turquie" (Turkey).

RANGe. E: AR GG GR (Rodos) A: LE SY TR (Danilevsky, 2019).

MARDIN. Mazıdağ, 05.VI.1976, fruit tree, det. Lodos, 1 ex (Tezcan et al., 2020a: 44).

Note. This record is, very likely, due to misidentification with the next species, separated recently for the East Turkey populations.

Stenurella Villiers, 1974

Stenurella Villiers, 1974. Type species: Leptura melanura Linnaeus, 1758 (original designation).

Stenurella bifasciata solaris Rapuzzi et Sama, 2012

Stenurella solaris Rapuzzi \& Sama, 2012. Type locality: Bitlis, $35 \mathrm{Km}$ E Tatvan, Turkey. 
RANGE. A: TR (Danilevsky, 2019).

MARDIN. Artuklu, Nur Mahallesi (Darzerke), 900 m., 31.V.2016, on flowers of Teucrium polium, M. Geçit leg. (MGPA).

Stictoleptura Casey, 1924

Brachyleptura (Stictoleptura) Casey, 1924. Type species: Leptura cribripennis LeConte, 1859 (original designation).

Stictoleptura (s.str.) cordigera cordigera Fueßlins, 1775

Leptura cordigera Fueßlins, 1775. Type locality: Luggaris (=Lovero, Italy).

RANGE. E: BE BU DE FR GB GE GR (northeast) IT NL RO SP SZ RO ST TR UK N: LB A: AB AR CY GG IN IQ IS LE SY TR (Danilevsky, 2019).

MARDIN. Artuklu, Sultan, Meadow, on flowers of Rubus sanctus, 1050 m., 27.06.2017, M. Geçit leg. (MGPA).

Note. The type locality is in Italy (Lovero, Sondrio province, Lombardia) and not in Switzerland as currently reported.

Stictoleptura (Paracorymbia) Miroshnikov, 1998 Paracorymbia Miroshnikov, 1998. Type species: Leptura fulva Degeer, 1775 (original designation).

Stictoleptura (Paracorymbia) cfr. sambucicola Holzschuh, 1982

Brachyleptura sambucicola Holzschuh, 1982. Type locality: Anatolien, Kilik. Taurus, Vill. Mersin, Namrun (Turkey).

RANGE. A: SY TR (Danilevsky, 2019).

MARdIN. Artuklu, Yaylabaşı Mah (Şatıh), on flower of Rosa damascena, 1050 m., 21.V.2018, M. Geçit leg. (MGPA).

Note. This record is based on a picture, and no specimens were available for study. According to the picture (actually a bad quality one), the elytral apex appears yellow. Because of this character, this specimen does not match with typical $S$. sambucicola. Therefore, waiting to examine some specimens to determine its true identity, we prefer for the moment to refer to this species as $S$. cfr. sambucicola.

Vadonia Mulsant, 1863

Vadonia Mulsant, 1863. Type species: Leptura unipunctata Fabricius, 1787 (designated by Fairmaire, 1864).

Vadonia unipunctata syricola Holzschuh, 1993 Vadonia unipunctata syricola Holzschuh, 1993. Type locality: Syria bor. occ., Djebel Ansariya, Abu Quaiez.

RANGE. A: LE SY (Danilevsky, 2019); TR (new record).

MARDIN. Artuklu, Hamzabey Mahallesi (Vadi Birkitılcemel), $940 \mathrm{~m}$. on flowering Malabaila secacul, 7.V.2016, M. Geçit leg. (MGPA).

RHAGIINI Kirby in Richardson, 1837

Raghiadae Kirby in Richardson, 1837. Type genus: Rhagium Fabricius, 1775.

Cortodera Mulsant, 1863

Cortodera Mulsant, 1863. Type species: Grammoptera spinosula Mulsant, 1839 (= Leptura humeralis Schaller, 1783).

Cortodera colchica Reitter, 1890

Cortodera colchica Reitter, 1890. Type locality: Kaukasus, Araxestal (Armenia).

RANGE. E: ST A: AB AR TR (Danilevsky, 2019).

Mardin. Artuklu, Hamzabey Mahallesi, on flowering Cyanus triumfettii, 01.V.2016 M. Geçit leg.; idem 07.V.2017 (MGPA).

Cortodera syriaca didemae Özdikmen, 2016 Cortodera orientalis didemae Özidikmen, 2016.

Type locality: Mardin (Turkey). Cortodera syriaca didemae: Danilevsky, 2019.

RANGE. A: TR (Özdikmen, 2016a).

Mardin. Mardin (type loc.); Mardin, Artuklu Nur Mahallesi (Darzerke), adults sitting on Gundelia sp. 950 m, 23.IV.2016, M. Geçit leg. (MGPA).

Note. Danilevsky (2019) wrote: "Cortodera orientalis didemae $O \ddot{z}$ dikmen, 2016 was described on 
the basis of a single male from SE Anatolia (Mardin prov. - without precise locality). The male does not belong to $\mathrm{C}$. orientalis because of short and wide body. It looks like C. syriaca Pic, 1901 with bicolored middle and hind legs, while all specimens of C. syriaca from Transcaucasia to Syria known to me have middle and hind legs black. Bicolored middle and hind legs are known in $\mathrm{C}$. syriaca nigroapicalis Holzschuh, 1981 from Hakkari prov. and in specimens from West Iran. So, until better study a new subspecies from Mardin can be accepted: C. syriaca didemae Ö̈dikmen, 2016".

In our opinion this subspecies should be synonymized with Cortodera syriaca ssp. nigroapicalis Holzschuh, 1981 because subsequently many species from Eastern Turkey and Western Iran have also been discovered in Mardin, and the characters used to separate this subspecies are the same used to separate the subspecies nigroapicalis. Therefore, we prefer to examine more specimens from this locality, before formalizing this synonymy.

CERAMBYCINAE Latreille, 1802

Cerambycinae Latreille, 1802

CALLICHROMATINI Swainson et Shukard, 1840 Callichrominae Swainson \& Shukard, 1840. Type genus: Callichroma Latreille, 1817.

Osphranteria Redtenbacher, 1850

Osphranteria Redtenbacher, 1850. Type species: Osphranteria suaveolens (designated by Thomson, 1864).

Osphranteria coerulescens Redtenbacher, 1850 Osphranteria coerulescens Redtenbacher, 1850. Type locality: Persia (Iran).

RANGe. A: IN IQ PA TR (Danilevsky, 2019).

MARDIN. Mardin (Heyden, 1894; Plavilstshikov, 1933; Kaplan, 2013); Artuklu, Nur Mahallesi (Darzerke), 900 m., 29.VI.2016., M. Geçit leg. ; Yenişehir Mahallesi, 947 m., 23.VI.2017 M. Geçit \& S. Tusun leg. (MGPA).

CERAMBYCINI Latreille, 1802

Cerambycini Latreille, 1802

Type genus: Cerambyx Linnaeus, 1758

Cerambyx Linnaeus, 1758
Cerambyx Linnaeus, 1758. Type species: Cerambyx cerdo Linnaeus, 1758.

Cerambyx cerdo cerdo Linnaeus 1758

Cerambyx cerdo Linnaeus, 1758. Type locality: "Italy, Germany".

Range. E: AL AU BE BH BU BY CR CT CZ FR GBi GE GR HU IR IT LA LU MA MC MD NL PL RO SK SL ST SV SZ TR UK YU N: MO A: TR (Danilevsky, 2019).

MARDIN. Hop Geçidi (Çinaralti vill.), $15 \mathrm{~km} \mathrm{NE}$ Mardin, 3723N 4051E, 16.V.2001 (MF).

Cerambyx dux (Faldermann, 1837)

Hammaticherus dux Faldermann, 1837. Type locality: Transcaucasia.

RANGE. E: BU MC ST UK A: AB AR GG IN IS JO LE SY (Danilevsky, 2019).

Mardin. Artuklu, Nur Mahallesi Hamzabey Mahallesi, 27.VI.2017, M. Geçit leg.; Artuklu, Nur Mahallesi (Darzerke), 22.VII.2016, M. Geçit leg.; Hamzabey Mahallesi (Vadi Birkitılcemel), 16.VI.2017, M. Geçit leg. (MGPA).

Cerambyx nodulosus nodulosus Germar, 1817

Cerambyx nodulosus Germar. Type locality: aus Krain (Carniola, Slovenia).

RANGE. E: AL BH BU CR GR IT MA MC RO SL ST TR UK YU A: AB AR CY GG LE TR (Danilevsky, 2019).

MARDIN. Hop Gec., 28.V (Adlbauer, 1992: 494; Özdikmen, 2013a: 76; Avgın et al., 2014: 8); Artuklu, Yaylacık (Küferdel) Leylak meadow, on flowers of Rubus sanctus, 1050 m., 27.VI.2017, M. Geçit; idem 6.VII.2017, M. Geçit, S. Tusun \& H. Cebeci leg. (MGPA).

CERTALLINI Fairmaire, 1864

Sténopérites (Cartallites) Fairmaire, 1868. Type genus: Cartallum Serville, 1834.

Certallum Dejean, 1821

Certallum Dejean, 1821. Type species: Saperda ruficollis Fabricius, 1787 (= Cerambyx ebulinus Linnaeus, 1767) (monotypy). 
Certallum ebulinum Linnaeus, 1767

Cerambyx ebulinus Linnaeus, 1767 . Type locality: "Gallia" (France).

RANGE. E: AL BU FR GR MA MC PT SP ST TR UK A: AB AR CY GG IN IQ IS JO LE SY TR N: AG EG LB MO TU (Danilevsky, 2019).

Mardin. Hop Geç.: Pinardere (Özdikmen, 2013a: 78); Hop Gec. 1100 m, 15 km NE Mardin, $37^{\circ} 22^{\prime} \mathrm{N} 40^{\circ} 53^{\prime} \mathrm{E}$, 9.5.2007, leg. E. Hajdaj (Coll. S. Kadlec, NMPC); Artuklu, Nur Mahallesi (Darzerke), 950 m., 14.IV.2016, M. Geçit (MGPA).

Certallum thoracicum (Sharp, 1880)

Cartallum thoracicum Sharp, 1880. Type locality: "Near Jeddah (Saudi Arabia)" (wrong locality). 2019).

RANGE. A: IN IQ IS JO LE SY TR (Danilevsky,

Mardin. Mardin (Coll. Frey, NMBS); Hop Gec., Mardin env., 11.-14.5.2005, leg. Orszulik (Coll. S. Kadlec, NMPC); Artuklu, Hamzabey Mahallesi (Vadi Birkitılcemel), 1001 m., on Cardaria draba, 23.IV.2017, M. Geçit leg.; idem, 11.IV.2018, M. Geçit \& S. Tusun leg. (MGPA).

CLYTINI Mulsant, 1839

Clytaires Mulsant, 1839.

Type genus: Clytus Laicharting, 1784.

Chlorophorus Chevrolat, 1863

Chlorophorus Chevrolat, 1863. Type species: Callidium annulare Fabricius, 1787

Chlorophorus varius damascenus (Chevrolat, 1854) Clytus damascenus Chevrolat, 1854. Type locality:

"'Environs de Damas"' (Syria).

Chlorophorus varius varius: Tezcan et al., 2020a: 94.

Chlorophorus damscenus: Özdikmen et al., 2016: 367.

RANGE. E: GR (Rodos) N: EG A: CY ?IN IS IQ JO LE SY TR (Danilevsky, 2019).

MARDIN. Mardin (Lodos, 1998); Mardin (Özdikmen et al., 2016); Artuklu, Nur Mahallesi (Darzerke), on flowers of Teucrium polium, $940 \mathrm{~m}$., 31.V.2016 Birey Geçit leg. (MGPA); Hop Geçidi, 1100 m., 9.V.2014, ex larva Ficus carica, emerged 18.VII.2014, P. Rapuzzi leg. (PRCU).
Plagionotus Mulsant, 1842

Plagionotus Mulsant, 1839 (new name for Platynotus Mulsant, 1839).

Type genus: Leptura detrita Linnaeus, 1758 (designated by Thomson, 1864).

Plagionotus (Echinocerus) Mulsant, 1862

Echinocerus Mulsant, 1862. Type species: Leptura floralis Pallas, 1773 (monotypy).

Plagionotus (Echinocerus) floralis (Pallas, 1773) Cerambyx floralis Pallas, 1773. Type locality: "Russia mer.".

RANGE. E: AL AU BH BU CR CT CZ FR GE GR HU IT LA LT MC MD NT PL RO SK SL SP ST SZ TR UK YU A: AB AR ES GG IN IQ IS JO KI KZ LE TD TM TR UZ WS XIN (Danilevsky, 2019).

MARDIN. Ömerli (Tezcan et al., 2020a: 51); Artuklu, Hamzabey Mahallesi (Vadi Birkitılcemel), on flowers of Malabaila secacul, 970 m., 21.V.2016, M. Geçit leg. (MGPA).

Plagionotus (Neoplagionotus) Kasatkin, 2005 Neoplagionotus Kasatkin, 2005. Type species: Clytus Bobelayei Brullé, 1832.

Plagionotus (Neoplagionotus) bobelayei mouzafferi Pic, 1905

Plagionotus Bobelayei var. Mouzafferi Pic, 1905. Type locality: Perse: de Susa à Ispahan (Iran).

RANGE. A: IN IQ IS JO SY TR (Danilevsky, 2019).

Mardin. Artuklu, Nur Mahallesi (Darzerke), 950 m., 19.V.2016, M. Geçit leg. (MGPA).

DEILINI Mulsant, 1862

Déilates Mulsant, 1862.

Type genus: Deilus Audinet-Serville, 1834

Delagrangeus Pic, 1892

Delagrangeus Pic, 1892. Type species: Delagrangeus angustissimus Pic, 1892 (by monotypy)

Edithia Reitter, 1899. Type species: Edithia carbonaria Reitter, 1899 (by monotypy)

Delagrangeus angustissimus angustissimus Pic, 1892 
Delagrangeus angustissimus Pic, 1892. Type locality: Haute Syrie, Akbez, Yeniyapan (Turkey).

Delagrangeus angustissimus: Plavilstshikov, 1931: 142

Edithia carbonaria Reitter, 1899. Type loc.: Mardin (Turkey)

\section{Delagrangeus angustissimus angustissimus Pic,} 1892

Delagrangeus angustissimus Pic, 1892. Type locality: Haute Syrie (very likely Turkey, Hatay province).

RANGe. A: TR (Danilevsky, 2019).

MARDIN. Mardin (Reitter, 1899, type locality of Edithia carbonaria; Mardin (Plavilstshikov, 1931).

HESPEROPHANINI Mulsant, 1839

Hesperophanaires Mulsant, 1839

Type genus: Hesperophanes Mulsant, 1839

Stromatium Audinet-Serville, 1834

Stromatium Audinet-Serville, 1834. Type species: Callidium barbatum Fabricius, 1775 (by monotypy).

Stromatium auratum Böber, 1793

Saperda aurata Böber, 1793. Type locality: Tauria (Crimea, Russia).

RANGE. E: AL BH BU CR FR GR HU IT MA MC PT RO SP ST TR UK YU A: AB AR CY GG IN IQ IS JO LE SY TM TR N: AG MO TU LB (Danilevsky, 2019).

MARDIN. Artuklu, Cevizlik village (Cewzat), 26.VII.2018, M. Geçit leg. (MGPA).

Trichoferus Wollaston, 1854

Trichoferus Wollaston, 1854. Type species: Trichoferus senex Wollaston, 1854.

Trichoferus ivoi Kadlec, 2005

Trichoferus ivoi Kadlec, 2005

Type locality: Iran, IR, pr. Buyer Ahmad-e Kuhgiluye, 5 km E Si Saht (Denar Mts.) $2465 \mathrm{~m}$ )

RANGE. A: IN (Danilevsky, 2019), TR (new record).

MARDIN. "Mardin" (GSCC).
Note. One old specimen preserved in Sama's collection. Recentely one more specimen was reared from a small branch of Ficus carica in Siirt prov., SE Eruh 14.V.2018, 1104 m. 37²' '59'N $42^{\circ} 15^{\prime} 15^{\prime \prime}$, P. Rapuzzi leg.

Trichoferus lunatus (Szallies, 1994)

Hesperophanes lunatus Szallies, 1994

Type locality: SO-Türkey, Mardin, Hop Gecidi

(holotypus in coll. Adlbauer, Graz).

RANGE. A: IN TR (Danilevsky, 2019).

MARdin. Hop pass, 1138 m, 28.VI.2010, one immature female in pupal cell and several fresh exit holes in Quercus sp.; idem, 14.V.2011, several larvae in twigs of Quercus sp. (one specimen emerged on 15.VI.2011); $6 \mathrm{~km}$ east of Arıçı, $1000 \mathrm{~m}$, larvae in twigs of Quercus sp.; $11 \mathrm{~km}$ east of Midyat, idem (Sama et al., 2012; Özdikmen, 2013a: 74).

Trichoferus preissi (Heyden 1894)

Hesperophanes preissi Heyden, 1894

Type locality: Mardin (Turkey).

RANGe. A: TR (Danilevsky, 2019).

MARDIN. Mardin (type loc.); Mardin (Özdikmen, 2013a: 74); Artuklu, Nur Mahallesi (Darzerke), 26.VI.2016, M. Geçit leg. (MGPA); Hop Geçidi, 1100 m., 9.V.2014, ex larva Ficus carica, emerged 18.VII.2014, P. Rapuzzi leg. (PRCU).

PURPURICENINI Thomson, 1860

Purpuricenini Thomson, 1860

Type genus: Purpuricenus Dejean, 1821

Calchaenesthes Kraatz, 1863

Calchanesthes Kraatz, 1863. Type species: Callidium oblongo-maculatum Guérin-Méneville, 1844 (original designation).

Calchaenesthes primis Özdikmen, 2013

Calchaenesthes primis Özdikmen, 2013. Type locality: Turkey: Içel.

RANGe. A: CY TR (Danilevsky, 2019).

MARDIN. Mardin (Özdikmen \& Cihan Tüzün, 2018: 109).

Purpuricenus Dejean, 1821 
Purpuricenus Dejean, 1821. Type species: Cerambyx kaehleri Linnaeus, 1758.

Purpuricenus apicalis Pic, 1905

Purpuricenus dalmatinus v. apicalis Pic, 1905. Type locality: Mar-Yacoub (Monastère SaintJacques) (Irak).

Purpuricenus dalmatinus: Özdikmen, 2008: 372; Avgin et al., 2014: 17.

RANGE. A: IN IQ TR (Danilevsky, 2019).

Mardin. Mardin (Özdikmen, 2008 sub P. dalmatinus (Sturm, 1843); Avgin et al., 2014 sub P. dalmatinus).

Note. In this area $P$. dalmatinus is replaced by P. apicalis, so all the records must be refered to apicalis. Moreover $P$. apicalis is recorded for a locality very close to Mardin province: Haberli (Sirnak prov.), 1020 m., 17-19.V.2001 (Sama et al., 2012).

\section{Purpuricenus budensis (Götz, 1783)}

Cerambyx budensis Götz, 1783. Type locality: Hungary, Osen.

Range. E: BH BU CT CR FR GR HU IT MC MD RO SK SL SP ST TR UK YU A: AB AR CY GG IS LE SY TR WS (Danilevsky, 2019).

MARDIN. Mardin (Tezcan et al., 2020a: 58).

Purpuricenus interscapillatus Plavilstshikov, 1937 Purpuricenus budensis v. interscapillatus Plavilstshikov, 1937. New name for Purpuricenus budensis v. humeralis Pic, 1891. Type locality: Asie Mineure (Turkey).

Purpuricenus interscapillatus ssp. interscapillatus: Rapuzzi \& Sama, 2013: 144

RANGe. A: SY TR (Danilevsky, 2019).

MARDIN. Mardin (Rapuzzi \& Sama, 2013); Mardin. Midyat (20 Km SO), 5.VI.1998, M. Snizek leg. (Coll. Kadlec, National Museum, Praha, Czech Republic); Haberli (1020 m) 33 km SE Midyat, 1719.V.2001 (GSCC); Mardin prov., Hop Geç., 1000 m., 9.V.2014, ex larva Quercus sp., emerged 30.V.2015, P. Rapuzzi leg. (PRCU).

Purpuricenus wachanrui Levrat, 1858

Purpuricenus wachanrui Levrat, 1858. Type locality: Turquie (Turkey).
RANGE. A: AB CY IN IQ SY TR (Danilevsky, 2019).

Mardin. Artuklu, Nur Mahallesi (Darzerke), 900 m., 19.V.2016, on flowers of Paliurus spinachristi, M. Geçit leg. (MGPA).

[Purpuricenus dalmatinus Sturm 1843]

Purpuricenus dalmatinus Sturm, 1843. Type locality: Dalmatien (Dalmatia, Croatia).

RANGE. E: BH BU CR GR IT MC SL A: IS JO LE SY TR (Danilevsky, 2019).

MARDIN. Mardin (Özdikmen, 2008; Avgın et al., 2014)

Note. As explained before, the records of this species must refered to $P$. apicalis that is vicariant in this area with this species.

STENOPTERINI Gistel, 1848

Stenopteridae Gistel, 1848 Gistel, 1848

Type genus: Stenopterus Illiger, 1804

Callimus Mulsant, 1846

Callimus Mulsant, 1846. Type species: Callimus bourdini Mulsant, 1846 (= Saperda angulata Schrank, 1789) (by monotypy).

Callimus (Lampropterus) Mulsant, 1862

Callimus (Lampropterus) Mulsant, 1862. Type species: Necydalis femoratus Germar, 1823 (by monotypy).

Callimus (Lampropterus) femoratus (Germar, 1823) Necydalis femoratus Germar, 1823. Type locality: Rossia meridionalis (Russia).

Callimellum adonis: Plavilstshikov, 1931: 103

RANGE. E: AL BU GR MC MD RO ST TR UK YU A: AB AR GG IN IS CY LE SY TR (Danilevsky, 2019).

MARDIN. Mardin (Plavilstshikov, 1931); Derik, 5.VI.1976 (Tezcan, 2020a: 55); MARDIN. Hop pass, $1138 \mathrm{~m}, 14 . \mathrm{V} .2011$, several adults in pupal cell on Quercus sp. (Sama et al., 2012); Çaglar vill., 37²2'59”N 4042'06”, 997 m., 13.V.2018, P. Rapuzzi leg. (PRCU). 
LAMINAE Latreille, 1825

Lamiaires Latreille, 1825

AGAPANTHIINI Mulsant, 1839

Agapanthaires Mulsant, 1839

Type genus: Agapanthia Serville, 1835.

Agapanthia Audinet-Serville, 1835

Agapanthia Serville, 1835

Type species: Saperda cardui Fabricius, 1801 (= Cerambyx cardui Linnaeus, 1767), designated by Westwood (1840).

Agapanthia (Agapanthia) suturalis (Fabricius, 1787)

Saperda suturalis Fabricius, 1787. Type locality: "Habitat in Africae plantis" (Barbarie, Algeria).

RANGE. E: FR GR (Dodecanissos) IT MA PT SP N: AG CI LB MO TU A: AB AR GG CY IN IS IQ JO LE SY TR (Danilevsky, 2019).

Mardin. Nur Mahallesi (Darzerke), $940 \mathrm{~m}$., 19.IV.2016, on Gundelia sp., M. Geçit leg.; idem, 8.V.2017 (MGPA).

Agapanthia (Agapanthoplia) Pesarini et Sabbadini, 2004

Agapanthoplia Pesarini \& Sabbadini, 2004

Type species: Agapanthia coeruleipennis Frialdszky, 1878 (original designation).

Agapanthia (Agapanthoplia) coeruleipennis Frivaldszky, 1878

Agapanthia coeruleipennis Frivaldszky, 1878. Type locality: Asia Minor (Turkey).

RANGE. A: IN SY TR (Danilevsky, 2019).

Mardin. Mardin (Özdikmen et al., 2005: 26; Özdikmen, 2013b: 98; Özdikmen, 2013b: 23); Mardin Artuklu, Nur Mahallesi (Darzerke), 900 m., 23.IV.2016, on Gundelia sp., M. Geçit leg.; Yaylac1k (Küferdel), Leylak meadow, $1080 \mathrm{~m}$., 18.IV.2018, on Gundelia sp., M. Geçit \& S. Tusun leg. (MGPA).

Agapanthia (Epoptes) Gistel, 1857

Epoptes Gistel, 1857

Type species: Saperda asphodeli Latreille, 1804 (original designation).
Agapanthia (Epoptes) dahli walteri Reitter, 1898 Agapanthia walteri Reitter, 1898. Type locality: Armenien: Erzerum. Kleinasien: Mardin (Turkey).

RANGe. A: AB AR GG IN TR (Danilevsky, 2019).

MARDIN. Mardin (Type locality); Mardin (Özdikmen, 2013b: 97; Özdikmen, 2013b: 22);Hop Geçidi (Çinaralti vill.) $15 \mathrm{~km} \mathrm{NE}$ Mardin, 3723N 4051E, 16.V.2001, M. Rejzek leg. (GSCC); Artuklu, Nur Mahallesi (Darzerke), 950 m., 29.IV.2016, M. Geçit leg.; Hamzabey Mahallesi (Vadi Birkitılcemel), 970 m., 26.V.2017, on Onopordon carduchorum, M. Geçit leg. (MGPA); Cevizpinari vill., 37, 423058N 40 7750896E, 13.V.2018, P. Rapuzzi leg. (PRCU).

Agapanthia (Epoptes) simplicicornis Reitter, 1898 Agapanthia simplicicornis Reitter, 1898. Type locality: Klein Asien, Mardin (Turkey).

RANGE. A: TR (Danilevsky, 2019).

MARDIN. Mardin (type locality); Mardin (Özdikmen, 2013b: 97; Özdikmen, 2013b: 20).

Agapanthia (Epoptes) verecunda Chevrolat, 1882 Agapanthia verecunda Chevrolat, 1882. Type locality: Syrie, in montibus Drusarum.

RANGE. A: TR (Danilevsky, 2019) SY (type locality).

MARDIN. Mardin (Önalp, 1989: 205); Mardin (Özdikmen, 2013b: 97; Özdikmen, 2013b: 21); Mardin (GSCC).

Agapanthia (Smaragdula) Pesarini et Sabbadini, 2004

Agapanthia subg. Smaragdula Pesarini et Sabbadini, 2004

Type species: Saperda violacea Fabricius, 1775 (original designation).

Agapanthia (Smaragdula) frivaldszkyi Ganglbauer, 1884

Agapanthia frivaldszkyi Ganglbauer, 1884. Type locality: Kleinasien (Turkey).

RANGe. E: BU RO A: IS IN IQ JO SY TR (Danilevsky, 2019). 
Mardin. Mardin, 3.VI.1976, Prunus dulcis (Tezcan et al. 2020b; 155); Nur Mahallesi (Darzerke), 940 m., 29.IV.2016, M. Geçit leg.; idem, 15.V.2017, M. Geçit \& S. Tusun leg. (MGPA); Cevizpinari vill., 37, 423058N - 40 7750896E, 13.V.2018, P. Rapuzzi leg. (PRCU); Çaglar vill., 37²1'56”N 4040'53'”E, 963 m., 13.V.2018, P. Rapuzzi leg. (PRCU); Çaglar vill., 37²1'30'N 4041'33'”E, 949 m., 13.V.2018, P. Rapuzzi leg. (PRCU).

Note. The indication of Prunus dulcis (Tezcan et al., 2020b) is evidentely wrong, the species is strictly oligophagous on Dipsacaceae.

Agapanthia (Smaragdula) lais Reiche et Saulcy, 1858

Agapanthia lais Reiche \& Saulcy, 1858. Type locality: "Peloponnese" (S Greece) (wrong locality).

RANGE. A: IS JO LE SY TR (Danilevsky, 2019).

MARDIN. Mardin (Onalp, 1988: 270; Özdikmen, 2013b: 98; Özdikmen, 2013b: 28).

\section{Agapanthia (Smaragdula) mardinensis Rapuzzi} n. sp. (Fig. 1)

https://zoobank.org:act:D65271BE-68C0-4F779CF1-76871CB5F187

TYPE SERIES. Holotype ${ }^{\lambda}$ : Turkey, MARDIN. Artuklu, Hamzabey Mahallesi (Vadi Birkitılcemel), 992 m., 01.V.2018, on Astragalus aleppicus, M.

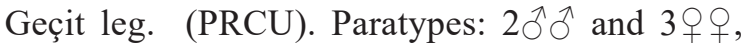
same data as the holotype, on Astragalus aleppicus and Astragalus babacianum; $1 \delta^{\uparrow}$ and 19 , same data as the holotype, 08.IV.2017, on Astragalus aleppicus (PRCU, MGPA); 10ิ MARDIN. Hop Geç. 11.IV.2014, A. Sabbadini leg. (PRCU).

DESCRIPTION OF THE HOLOTYPE MALE. Length 8.3 $\mathrm{mm}$., humeral width $1.8 \mathrm{~mm}$. Elytra bluish-green, head and pronotum golden-green, with metallic shine. Head deeply punctured, with denser punctures on the vertex than on the frons. Frons large, with a central short and shallow furrow starting at the insertion of the antennae and reaching the middle of the frons, with dense and large punctures, the space between them being somewhat wider than the diameter of a single puncture. Pubescence of the head black, with long and erect setae which are denser on vertex and frons. Inner ocular margin densely bordered with recumbent white setae. The same kind of pubescence covers the outer margin of the mandibles.

Antennae long, exceeding the elytral apex by the last six segments. Scape and pedicellum metallic blue, the following antennomeres darker, only slightly metallic blue. Scape with punctures rather large, thick and deep, while on the following segments they are smaller and denser.

Pronotum as long as wide. Lateral margins sinuate, enlarged just behind the middle and narrowed close to the apex and base. Surface densely covered by punctures of regular size, with space between them distinctly smaller than the size of a single puncture. Close to the apical portion the sculpture is arranged in transverse wrinkles. A few wrinkles are also present on the discal area, although very small and short. Pubescence consisting in very long, erect, black setae, slightly denser on the sides.

Scutellum deep-blue, short, wider than long, oval shaped, its surface glabrous, punctate and with a very thin median line.

Elytra long, constricted toward the apex, with apex rounded. Elytral surface deeply punctured, with very dense and deep punctures, the space between the punctures is covered by a micro-sculpture that gives a matte aspect to the elytra. Basal elytral portions slightly depressed between the scutellum and the humeral angle. Elytral pubescence composed of two different kind of setae, the more evident one made of very long black bristles, dense and erect; between these bristles is found a dense basal pubescence, shorter and partially recumbent toward the elytral apex, dark-brown. The elytral ground color is metallic blue, except for the lateral margin and the apex which are metallic green.

Legs long, green, covered with long, erect, black setae scattered between a dense, shorter and recumbent grey pubescence.

VARIABILITY. The body size of males shows a length ranging between $8-9 \mathrm{~mm}$ and an humeral width between $1.8-1.9 \mathrm{~mm}$. The females show a range of length between 11.0 and $12.5 \mathrm{~mm}$, and an humeral width between 2.9 and $3.1 \mathrm{~mm}$. Two paratypes show darker blue elytra. The female differs from the male by the shorter antennae, a more parallel elytral shape, and the larger size.

Biology. All the known specimens were collected on leaves of Astragalus aleppicus and Astra- 


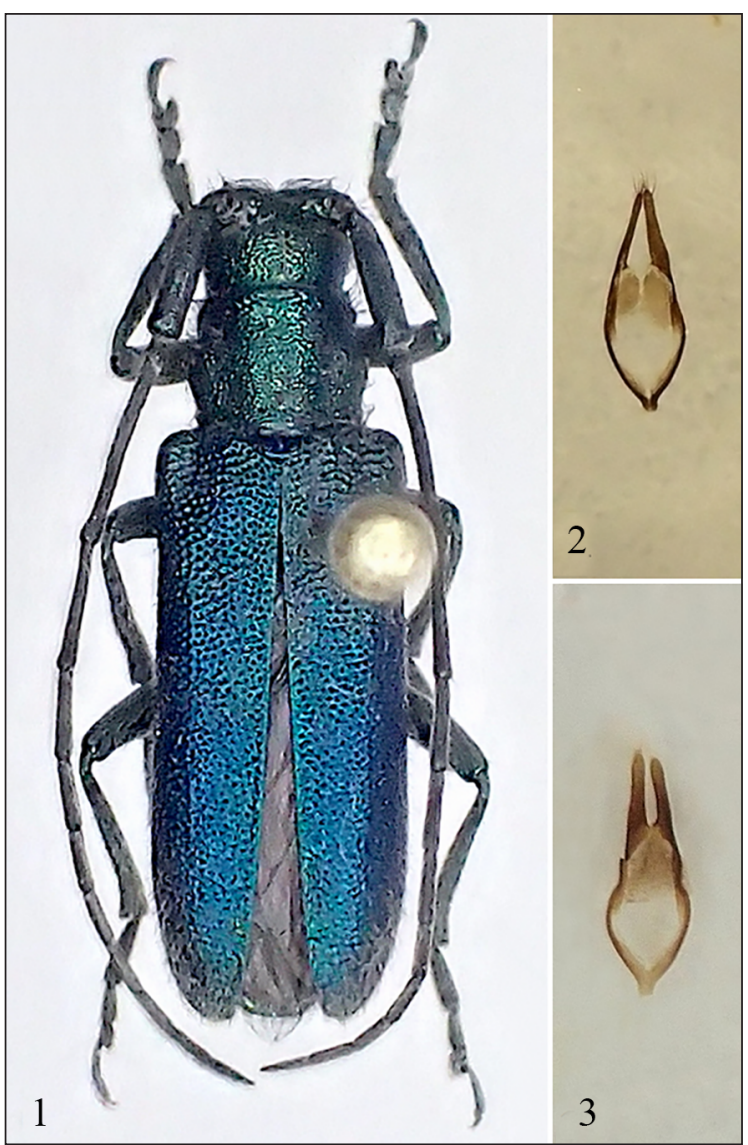

Figure 1. Agapanthia (Smaragdula) mardinensis Rapuzzi n. sp. Holotype male. Figure 2. Agapanthia (Smaragdula) mardinensis n. sp. Paramers. Figure 3. Agapanthia (Smaragdula) naciyae Rapuzzi \& Sama, 2012. Paramers.

galus babacianum (Fabaceae), which also very likely represent the host-plant of the new species.

REMARKS. The new species is related to Agapanthia naciye Rapuzzi et Sama, 2012 described from Eastern Turkey (Erzincan: $12 \mathrm{Km}$ W Refahiye), and to Agapanthia petranyi Kotán, 2014 (Iran, Kordestan, Sanandag, Askaran); taken together they seemingly form an homogenous group of species, characterized by the wide shape of body and the short antennae, and are ecologically connected with Astragalus host-plants. Agapanthia mardinesis is easily distinguished from the other species of the same group by its bicolored body: head and pronotum always golden-green, and blue elytra. The new species also differs from $A$. naciyae by the few wrinkles on the pronotal disc which are totally missing in A. naciyae. From A. petranyi the new species differs by the less stout shape of the body, and the more slender pronotum. The furrow in the middle of the head is longer and deeper in the Iranian species.

The parameres of the new species are very distinctive compared with the closest species ( $A$. naciyae) for the shape. In fact, they are smaller, oval shaped instead longer and sinuate at the base and with a denser touft of hairs at the apex (Figs. $2,3)$.

Agapanthia (Smaragdula) cfr. violacea (Fabricius, 1775)

Saperda violacea Fabricius, 1775. Type locality:

"Regio Pedemontana" (Piemonte, Italy).

RANGe. E: AL AU BE BU CT CR CZ FR GE GR HU IT LA LU MC MD NT PL PT SK SL SP ST TR UK YU A: AB AR ES GG KZ TR (Danielvsky, 2018).

Mardin. Hop Gecidi, Mardin env., 11.14.5.2005, leg. Orszulik (NMPC).

Agapanthia (Synthapsia) kirbyi Gyllenhal, 1817 Saperda kirbyi Gyllenhal, 1817. Type locality: "Lusitania“"(Portugal).

RANGE. E: AL BH BU CR CT FR GR HU IT IQ KZ MD RO SK SP ST TR UK YU A: AB AR GG IN IS SY TM TR (Danilevsky, 2019).

MARDIN. Ömerli, 12.VI.1972, Platanus orientalis (Tezcan et al., 2020b: 154); Nur Mahallesi (Darzerke), 940 m. 15.V.2016, on Verbascum lasianthum, M. Geçit leg.; idem, 26.V.2017 (MGPA).

Note. The indication of Platanus (Tezcan et al., 2020 b) is evidentely wrong, indeed this species is strictly monophagous on Verbascum.

\section{DORCADIONINI Swainson, 1840}

Dorcadioninae Swainson, 1840

Type genus: Dorcadion Dalman, 1817.

\section{Dorcadion Dalman, 1817}

Dorcadion Dalman, 1817

Type species: Cerambyx glicyrrhizae Pallas, 1771 (designed by Thomson, 1864).

Dorcadion (Cribridorcadion) Pic, 1901 Dorcadion subgenus Cribridorcadion Pic, 1901 
Type species: Dorcadion mniszechi Kraatz, 1873 (original designation).

Dorcadion (Cribridorcadion) accola Heyden, 1894 Dorcadion accola Heyden, 1894. Type locality: Mardin (Turkey).

RANGE. A: TR (Danilevsky, 2019).

MARDIN. Mardin (type locality); Mardin (Braun, 1978: 109; Özdikmen, 2013a: 82: Özdikmen, 2016a: 2403); Mardin; Mardin, Savur-Midyat, 10.IV.1979 V. Günes, leg. (Onalp, 1991: 219); Artuklu, Nur Mahallesi (Darzerke), $950 \mathrm{~m}$., 05.IV.2017, M. Geçit. leg.; Hamzabey Mahallesi (Vadi Birkitılcemel), 1200 m., 11.IV.2017, M. Geçit \& S. Tusun leg. (MGPA).

Dorcadion (Cribridorcadion) carinipenne Pic, 1900 Dorcadion carinipenne Pic, 1900. Type locality: Haute Syrie: Akbès (Turkey).

RANGE. A: TR (Danilevsky, 2019).

MARDIN. Mardin (Taurus) (NMBS, ex coll. Breuning).

\section{Dorcadion (Cribridorcadion) mesopotamicum} Breuning, 1944

Dorcadion (Pedestredorcadion) mesopotamicum Breuning, 1944. Type locality: "Mesopotamie, Ras Elain" (NE Syria).

Dorcadion (Pedestredorcadion) mesopotamicum $\mathrm{m}$. submardinense Breuning, 1946: 109.

RANGe. IQ TR (Danilevsky, 2019) ; SY (Breuning, 1944).

Mardin. Mardin (type locality of Dorcadion (Pedestredorcadion) mesopotamicum m. submardinense Breuning, 1946: 109); Mardin (Özdikmen, 2013a: 85; Özdikmen 2016a: 2429).

\section{Dorcadion (Cribridorcadion) oezdurali Önalp,} 1988

Dorcadion oezdurali Önalp, 1988

Type loc.: Turkey, Kahramanmaras, Ahir daği.

Dorcadion divisum m. intercisum: Braun, 1978: 113.

RANGE. A: TR (Danilevsky, 2019).

Mardin. Akresi Pass, m. 1000, IV.1976, leg,
Heinz (Braun, 1978 sub Dorcadion divisum m. intercisum Kraatz, 1873) (Özdikmen, 2016a: 2411, sub Dorcadion catenatum ssp. intercisum).

Note. In our opinion this record should be referred to Dorcadion (Cribridorcadion) oezdurali Önalp, 1988, the only species known from SE Turkey (Adiyaman prov., Kahramanmaras, prov., Özdikmen, 2010: 453) with similar elytral drawing.

Dorcadion (Cribridorcadion) schultzei Heyden, 1894

Dorcadion schultzei Heyden, 1894. Type locality: Mardin (Turkey).

RANGe. A: TR (Danilevsky, 2019).

MARDIN. Mardin (1 PT, Coll. Lepesme, MCLF); Mazıdağı b. Mardin, m.800, IV.1976; Akresi pass b. Mardin, m.1000, IV. 1976, leg. Heinz (Braun, 1978: 112); Mardin (Özdikmen, 2013a: 86; Özdikmen, 2016a: 2442); Gurpinar, m.900, b. Mazıdağ1 (NMBS); Hop Geçidi (Çinaralti vill.) $15 \mathrm{~km} \mathrm{NE}$ Mardin, 3723N 4051E, 16.V.2001; $10 \mathrm{~km} \mathrm{NE}$ of Mardin, 900 m - 11.4.1992, B. Zvarič leg.; Hop Gecidi, Mardin env., 11.-14.5.2005, Z. Malinka leg. (NMPC).

\section{[Dorcadion (Cribridorcadion) delagrangei Pic,} 1894]

Dorcadion delagrangei Pic, 1894. Type locality: Haute Syrie: Akbès (Turkey).

Dorcadion accola var. mardinense Pic, 1900. Type locality: Mardin (Turkey).

RANGe. A: TR (Danilevsky, 2019).

MARDIN. Mardin (Pic, 1900; Özdikmen, 2016a).

Note. The record is based on the description of D. accola var. mardinense Pic, 1900 originally described as a variation of $D$. accola and later transferred to D. delagrangei by Breuning (1962: 273). Very likely it is simply a variation of $D$. accola due to the sympatric distribution of these forms. To confirm the real presence of this species in Mardin area it will be necessary to study the type specimen preserved in Pic's collection. In our opinion D. accola and $D$. delagrangei are two distinct species, the first one distributed in the eastern region of Hatay region and the second one from Hatay to Adana provinces and mardinense must be a synonym of $D$. accola. 
[Dorcadion (Cribridorcadion) hellmanni Ganglbauer, 1884]

Dorcadion hellmanni Ganglbauer, 1884. Type locality: Persien (Iran).

RANGe. A: IN IQ TR (Danilevsky, 2019).

Mardin. Hop pass, 1138 m, 14.V.2011, one dead specimen under stones (Sama et al., 2012: 35; Özdikmen, 2013a: 84; Özdikmen, 2016a: 2421).

Note. This record is incorrect due to misidentification and must be referred to D. accola Heyden, 1894. For this reason, the species is deleted from the list of species from MARDIN.

PHYTOECIINI Mulsant, 1839

Phytoeciares Mulsant, 1839. Type genus: Phytoecia Dejean, 1835.

Micromallosia Pic, 1900

Micromallosia Pic, 1900. Type species: Micromallosia Theresae Pic, 1900 (by monotypy).

Micromallosia theresae Pic, 1900

Micromallosia Theresae Pic, 1900. Type locality: Kurdistan, Mardin (Turkey).

RANGE. A: TR (Danilevsky, 2019).

MARDIN. Mardin (Type locality).

Oxylia Mulsant, 1862

Oxylia Mulsant, 1862

Type species: Phytoecia languida Ménétries, 1838 (by monotypy).

Oxylia argentata languida (Ménetries, 1838)

Phytoecia longuida (sic!) Ménétriés, 1838. Type locality: "entre Costantinople et le Balkan; Syrie".

Range. A: CY IN IQ IS JO LE SY TR (Danilevsky, 2019).

MARDIN. Ömerli, 3.VI.1976 (Tezcan et al., 2020b: 150); Hop Geçidi (Çinaralti vill.), $15 \mathrm{~km} \mathrm{NE}$ Mardin, 3723N 4051E, 16.V.2001 (Coll. M. Rejzek, Norwich, UK); Yaylacık (Küferdel), Leylağ Çayırı, 1080 m., on Echium italicum, 15.V.2016, M. Geçit leg. (MGPA).
Phytoecia Dejean, 1835

Phytoecia Dejean, 1835

Type species: Saperda cylindrica Fabricius, 1775 (= Cerambyx cylindricus Linnaeus, 1758), designated by Breuning (1952).

Phytoecia (Phytoecia) aenigmatica Sama, Rapuzzi et Rejzek, 2007 (Fig. 6)

Phytoecia aenigmatica Sama, Rapuzzi \& Rejzek, 2007. Type locality: $10 \mathrm{Km}$ NE Nesapur, Khordestan (Iran).

RANGe. A: IN (Danilevsky, 2019); TR (new record)

MARDIN. Artuklu, Hamzabey Mahallesi (Vadi Birkitılcemel), 976 m., 06.IV.2017, on Conium maculatum, M. Geçit leg. (MGPA).

Note. Two more female specimens were collected in Iran after the description: SSE Yasuj (Buyer Ahmad-o-Kuhgiluye), NE of Malashoreh pass., $2390 \mathrm{~m} ., \quad 30^{\circ} 29^{\prime} 24^{\prime \prime} \mathrm{N} \quad 51^{\circ} 39^{\prime} 29^{\prime \prime} \mathrm{E}$, 10-13.V.2016, G. Magnani \& D. Baiocchi leg. (PRCU).

\section{Phytoecia (Phytoecia) bangi Pic, 1897}

Phytoecia bangi Pic, 1897. Type locality: Mardin (Turkey).

RANGe. A: AR GG IN TR (Danilevsky, 2019).

MARDIN. Mardin. Type locality (Pic, 1897: 189; Holzschuh, 1975: 103; Özdikmen, 2013a: 94; Özdikmen, 2017: 113).

Phytoecia (Phytoecia) caerulea caerulea (Scopoli, 1772)

Leptura caerulea Scopoli, 1772. Type locality: "Carniola" (Slovenia).

RANGE. E: AL AU BH BU BY CR ?CT CZ GR HU IT IT MC MD PT RO SK SL SP ST SZ TR UK YU A: AB AR GG IN KZ SY TD TM TR UZ WS (Danilevsky, 2019).

Mardin. Artuklu, Nur Mahallesi (Darzerke), 920 m., on Sisymbrium orientale (Brassicaceae), 17.IV.2017, M. Geçit leg. (MGPA).

Phytoecia (Phytoecia) centaureae Sama et Rapuzzi, 2006 
Phytoecia centaureae Sama \& Rapuzzi, 2006. Type locality: Iran, Kordestan: $13 \mathrm{Km}$ S Saqqez.

RANGE. A: IN (Danilevsky, 2019); TR (new record).

MARDIN. Çaglar vill., 37²2'59'” 4042'06”, 997 m., 13.V.2018, on Centaurea behen (Asteraceae), P. Rapuzzi leg. (PRCU).

Phytoecia (Phytoecia) croceipes Reiche et Saulcy, 1858

Phytoecia croceipes Reiche \& Saulcy, 1858.

Nomen novum per Phytoecia puncticollis Mulsant et Wachanru, 1852, nec Faldermann, 1837. Type locality: Caramania (Turkey).

RANGe. A: AB AR CY GG IQ IN IS LE SY TR (Danilevsky, 2019).

Mardin. Mardin. Hop Geçidi, (Cinaralti vill.), 15 km NE Mardin, 3723N 4051E, 16.V.2001, leg. \& coll. Kabatek; $6 \mathrm{~km}$ east of Arıç1, $1000 \mathrm{~m}$, 14.V.2011 (Sama et al., 2012: 41; Özdikmen, 2013a: 94); Mardin (Özdikmen, 2017: 113); Hop gecidi, Mardin env., 11-14.5.2005, Z. Malinka leg. (Coll. S. Kadlec NMPC); Hamzabey Mahallesi (Vadi Birkit1lcemel), 976 m., on Centaurea behen, 30.III.2017, M. Geçit \& S. Tusun leg. (MGPA).

Phytoecia (Phytoecia) geniculata geniculata Mulsant, 1862

Phytoecia geniculata Mulsant, 1862. Type locality: Turkey.

RANGE. A: CY IN IQ IS JO LE TR (Danilevsky, 2019).

Mardin. Artuklu, Nur Mahallesi (Darzerke), 940 m., on Centaurea behen, 28.IV.2016, M. Geçit leg.; Hamzabey Mahallesi (Vadi Birkit1lcemel), 976 m., on Centaurea behen, 30.III.2017, M. Geçit \& $\mathrm{S}$. Tusun leg. (MGPA).

Phytoecia (Phytoecia) manicata Reiche et Saulcy, 1858 Phytoecia manicata Reiche \& Saulcy, 1858. Type locality: Siria (Syria).

RANGe. A: IS LE SY TR (Danilevsky, 2019).

Mardin. Mazıdağı, 05.VI.1996 (Tezcan et al., 2020b: 152).
Phytoecia (Phytoecia) pubescens Pic, 1895

Phytoecia manicata v. pubescens Pic, 1895. Type locality: Syrie.

RAnge. E: BH BU CR GR MC ST TR A: AB AR GG IN IS JO LE SY TR (Danilevsky, 2019).

Mardin. Hamzabey Mahallesi (Vadi Birkitılcemel), 976 m., 25.V.2017, on Bunium paucifolium (Apiaceae), M. Geçit leg. (MGPA).

Phytoecia (Phytoecia) virgula virgula (Charpentier, 1825)

Saperda virgula Charpentier, 1825. Type locality: Dalmatia (Croatia).

RANGE. E: AL AU BH BU BY CR CT CZ FR GE GR HU IT LA LT MC MD PL PT RO SK SL SP ST SZ TR UK YU A: AB AR CY ES GG IN IS JO KI KZ LE SY TD TM TR UZ WS XIN (Danilevsky, 2019).

MARDIN. Hamzabey Mahallesi (Vadi Birkitılcemel), 976 m., on Lepidium draba (Brassicaceae), 10.IV.2017, M. Geçit leg.; idem, 14.IV.2018., M. Geçit \& S. Tusun leg. (MGPA); Caglar vill., 37²2'59'N 4042'06", 997 m., 13.V.2018, P. Rapuzzi leg. (PRCU).

Phytoecia (Helladia) Fairmaire, 1864

Helladia Fairmaire, 1864.

Type species: Phytoecia flavescens Brullé, 1832.

Phytoecia (Helladia) adelpha Ganglbauer, 1886 Phytoecia (Helladia) adelpha Ganglbauer, 1886. Type locality: Syrien.

Phytoecia (Helladia) adelpha: Özdikmen \& Turgut, 2010: 323.

Phytoecia ferruggata var. houskai Heyrovsky, 1948. Type locality: Sultan, Nord Mardin (Turkey). Synonymy in Holzschuh, 1980: 574. Phytoecia ferrugata var. houskai: Fuchs \& Breuning, 1971: 438.

RAnge. A: AR CY SY TR (Danilevsky, 2019).

MARDIN. Sultan meadow, Nordlich Mardin (type locality of Phytoecia ferrugata var. houskai Heyrovsky, 1948); Mardin (Fuchs \& Breuning, 1971); MARDIN. Sultan (Özdikmen \& Turgut, 2010); MARDIN. Sultan meadow. Mardin (Fuchs \& Breuning, 1971); Sultan (Özdikmen, 2013a: 91); SE. 
Turkey, Hop Geçidi (Çinaralti vill.), 15 km NE. Mardin, $37^{\circ} 23^{\prime} \mathrm{N} 40^{\circ} 51^{\prime} \mathrm{E}, 16$. V.2001, M. Rejzek leg. (PRCU, GSCC).

Phytoecia (Helladia) armeniaca Frivaldszky 1878 Phytoecia armeniaca Frivaldszky, 1878. Type locality: Diarbekir, leg. Kindermann (Turkey).

Range. A: AB AR GG IS JO LE SY TR (Danilevsky, 2019).

MARDIN. Mardin, 1300 m., 10/15.V.69, Schubert (GSCC ).

Phytoecia (Helladia) ferrugata Ganglbauer, 1884 Phytoecia ferrugata Ganglbauer, 1884. Type locality: Haifa (Israel).

Phytoecia (Helladia) dilaticollis T. Pic, 1900. Type locality: Mardin (Turkey).

RANGE. A: IS JO LE SY TR (Danilevsky, 2019).

MARDIN. Mardin (type locality of dilaticollis T. Pic, 1900); Mardin, Sultan (Fuchs \& Breuning, 1971: 438 as Phytoecia ferrugata houskai Heyrovsky, 1948; Özdikmen, 2013a: 92).

Phytoecia (Helladia) imperialis (Sama et Rejzek, 2001)

Helladia imperialis Sama \& Rejzek, 2001. Type locality: NW Iran, Azarbaygan-e-Garbi, Serou.

RANGE. A: IN (Danilevsky, 2019) TR (Rejzek et al., 2003).

MARDIN. Hop Geçidi (Çinaralti vill.) $15 \mathrm{~km} \mathrm{NE}$ Mardin, $37^{\circ} 23^{\prime} \mathrm{N} 40^{\circ} 51^{\prime} \mathrm{E}, 16 . \mathrm{V} .2001$, S. Kadlec leg. (Rejzek et al., 2003: 175; NMPC).

Phytoecia (Helladia) humeralis humeralis (Waltl, 1838)

Saperda humeralis Waltl. Type locality: "Turken" (Turkey).

RANGE. E: GR (Rodos) TR A: AB CY GG IN IQ IS LE SY TR (Danilevsky, 2019).

MARDIN. Hop Geç (Çinaralti vill.) (Rejzek et al., 2003: 174); Hop Pass (Özdikmen, 2013a: 331); Hop Geçidi (Çinaralti vill.) $15 \mathrm{~km}$ NE Mardin, $37^{\circ} 23^{\prime} \mathrm{N} 40^{\circ} 51^{\prime} \mathrm{E}, 16 . \mathrm{V} .2001$; Hop Geç. 1100 m, 15 km NE Mardin, $37^{\circ} 22^{\prime} \mathrm{N} 40^{\circ} 53^{\prime} \mathrm{E}$, 9.5.2007, leg. E. Hajdaj (Coll. S. Kadlec NMPC); Şatih Mahallesi,
13.V.2018, M. Geçit leg. (MGPA); Cevizpinari vill., 37, 423058N 40 7750896E, 13.V.2018, P. Rapuzzi leg. (PRCU).

Phytoecia (Helladia) pretiosa fatima Ganglbauer, 1884

Phytoecia fatima Ganglbauer, 1884. Type locality: Persien (Iran).

RANGe. A: AB IN SY TR (Danilevsky, 2019).

MARDIN. Mardin, Hop pass, Çinaralti vill., 16.V.2001 (Rejzek et al., 2003: 176); MARDIN. Hop pass (Özdimen \& Turgut, 2010: 327 sub Phytoecia (Helladia) fatima); MARDIN. Hop Gecidi, 1115 m., Pinardere, 3.V.2000 (coll. Mauro Malmusi, Modena, Italy); SE. Turkey: Hop Geçidi (Çinaralti vill.), 15 km NE. Mardin, 3723N 4051E, 16.V.2001, Onopordum carduchorum (Asteraceae) (GSCC); Hop Geçidi (Çinaralti vill.) $15 \mathrm{~km}$ NE Mardin, 3723N 4051E, 16.V.2001 (GSCC); Hop Gec. 1100 m, 15 km NE Mardin, $37^{\circ} 22^{\prime} \mathrm{N} 40^{\circ} 53^{\prime} \mathrm{E}$, 9.5.2007, leg. E. Hajdaj (NMPC); Artuklu, Nur Mahallesi (Darzerke), 940 m., 18.IV.2016, on Onopordum carduchorum, M. Geçit leg.; idem, 19.IV.2017, M. Geçit leg. (MGPA).

[Phytoecia (Helladia) pretiosa pretiosa Faldermann, 1837]

Phytoecia pretiosa Faldermann, 1837. Type locality: Transcaucasia.

RANGE. E: ST A: AB AR GG IN ?LE TR (Danilevsky, 2019).

MARDIN. Alannyurt E of Gercüs, 18.V.2001, M. Rejzek leg.; Çinaralti vill., Hop pass, 1115 m., towards Pinardere, 3.V.2000, M. Malmusi \& L. Saltini leg. (Sama et. al., 2007: 167); 6 km east of Arıçlı, $1000 \mathrm{~m}, 14$.V.2011, two specimens sitting on Onopordum sp. (Asteraceae) (Sama et al., 2012: 40).

NOTE. Identification wrong. All the records must be refered to Phytoecia (Helladia) fatima Ganglbauer, 1884.

Phytoecia (Musaria) Thomson, 1864

Musaria Thomson, 1864.

Type species: Leptura affinis Harrer, 1784 (original designation).

Phytoecia (Musaria) affinis tuerki Ganglbauer, 1884 
Phytoecia türki Ganglbauer, 1884. Type locality: Brussa in Kleinasien (Turkey). 2019)

RANGE. E: BU TR A: SY TR (Danilevsky,

MARdin. $10 \mathrm{~km}$ E Mydiat, $800 \mathrm{~m}, 37^{\circ} 22^{\prime} \mathrm{N}$ $42^{\circ} 09^{\prime} \mathrm{E}, \quad 10.5 .2007$, leg. ${ }^{\circ} 17^{\prime} \mathrm{N} \quad 41^{\circ} 35^{\prime} \mathrm{E}$, 17-19.V.2001; Hop Geçidi (Çinaralti vill.) $15 \mathrm{~km}$ NE Mardin, 37²3’N 405'ㄹ'E, 16.V.2001 (GSCC); Artuklu, Hamzabey Mahallesi (Vadi Birkitılcemel), 970 m., on Salvia bracteata (Lamiaceae), 16.V.2017, M. Geçit leg. (MGPA).

\section{Phytoecia (Musaria) puncticollis puncticollis Fal-} dermann, 1837

Phytoecia puncticollis Faldermann, 1837. Type locality: Transcaucasia.

Phytoecia mardiniensis Heyden, 1894. Type locality: Mardin (Turkey).

Range. E: ST A: AB AR GG IN IQ TR (Danilevsky, 2019).

MARDIN. Mardin (Heyden, 1894, type locality of Phytoecia mardinensis); Mardin (Pic, 1952); Hop Gec. 1100 m, 15 km NE Mardin, 37²2'N 4053’E, 9.5.2007, leg. E. Hajdaj (Coll. S. Kadlec NMPC); Artuklu, Nur Mahallesi (Darzerke), 940 m., 27.IV.2016, on Eryngium sp. (Apiaceae), M. Geçit leg.; Yayla Mahallesi, Sultan meadow, 1080 m., 16.IV.2017, M. Geçit leg. (MGPA).

Phytoecia (Musaria) wachanrui Mulsant, 1851 Phytoecia wachanrui Mulsant, 1851. Type locality: "Turquie" (Turkey).

Phytoecia (Musaria) wachanrui v. obscuricornis Pic, 1897. Type locality: Asie Mineure: Mardin (Turkey).

Phytoecia mardinensis Aurivillius, 1923. Type locality: Kleinasien, Mardin (Turkey).

RANGE. E: GR (Rodos) ST A: IN IS JO LE SY TR (Danilevsky, 2019).

Mardin. Mardin (Type locality of Phytoecia wachanrui v. obscuricornis Pic, 1897 and Phytoecia mardinensis Aurivillius, 1923); Mardin (Özdikmen, 2013a: 93).

Phyyoecia (Neomusaria) Plavilstshikov, 1928 Phytoecia (Neomusaria) Plavilstshikov, 1928. Type species: Saperda balcanica Frivaldsky, 1835 (designed by Breuning, 1951).

\section{Phytoecia (Neomusaria) balcanica (Frivaldsky 1835)}

Saperda balcanica Frivaldszky, 1835. Type locality: Szlivnó (= Slivno, Bulgaria).

RANGE. E: BU GR TR A: IN IQ TR (Danilevsky, 2019).

MARDIN. Mardin (Özdikmen, 2013a: 93; Özdikmen, 2016b: 495); Haberli (1020 m) $33 \mathrm{~km} \mathrm{SE}$ Midyat, $37^{\circ} 17^{\prime} \mathrm{N} 41^{\circ} 35^{\prime} \mathrm{E}, 17-19 . \mathrm{V} .2001$; Hop Geçidi (Çinaralti vill.) $15 \mathrm{~km}$ NE Mardin, $37^{\circ} 23^{\prime} \mathrm{N}$ 4051'E, 16.V.2001 (GSCC); Artuklu, Hamzabey Mahallesi (Vadi Birkitılcemel), 970 m., on Salvia bracteata (Lamiaceae),16.V.2017, M. Geçit lgt. (MGPA)

\section{Phytoecia (Neomusaria) mesopotamica barbarae}

Rapuzzi n. ssp. (Fig. 9)

https://zoobank.org:act:9C98D6F4-1A75-4AC7961D-BC2BB9BFDC51

TYPE SERIES. Holotype ${ }^{\top}$ : Turkey, Mardin, Artuklu, Hamzabey Mahallesi (Vadi Birkitılcemel), 976 m., 06.IV.2017, on Conium maculatum (Apiaceae), M. Geçit \& S. Tusun leg. (PRCU). Paratypes: $1 \delta^{\lambda}$ and $1+$ with same data of the holotype (PRCU).

DESCRIPTION OF THE HOLOTYPE MALE. Length $11.5 \mathrm{~mm}$., humeral width 2,0 mm. Body black except for the legs which are partially yellowish. Body covered by light pubescence, greenish-grey on the elytra and orange on head, pronotum and scutellum. Area around the eyes glabrous, black. Head and the pronotum showing several thin, very long, erect black setae, denser on the frons than on the rest of the head. Antennae black, nearly glabrous, with only very few, erect and thin black setae on the inner side.

Pronotum slightly longer than wide, with two distinct glabrous black spots anteriorly on the disk. Elytra long, narrowed towards the apex, with apex truncate. Surface with light pubescence that hides the elytral sculpture. Few very long and erect, silver setae near the base, denser on lateral margins. Front legs yellowish except base of femora black. Middle legs bicolored, femora black, orange centrally, tibiae black, orangish basally. Hind femora narrowly 
marked with orange centrally, tibiae with a very small spot of orange on the outer side apically. Tarsi black. Ventral surface black, covered by orange pubescence, denser on the ventral side of the abdomen and metaventrite. Prosternum and ventral side of the head more densely covered by homogenous orange pubescence.

VARIABILITY. Females are stouter, with more par- allel elytra. Antennae and legs are slightly shorter than in males. The size ranges between $11.5 \mathrm{~mm}$ and $12.5 \mathrm{~mm}$ for the males, while the female is 11.5 $\mathrm{mm}$ long.

Biology. All type specimens of this new subspecies were collected together with Phytoecia aenigmatica on leaves of Conium maculatum (Apiceae), which very likely represents its host plant.

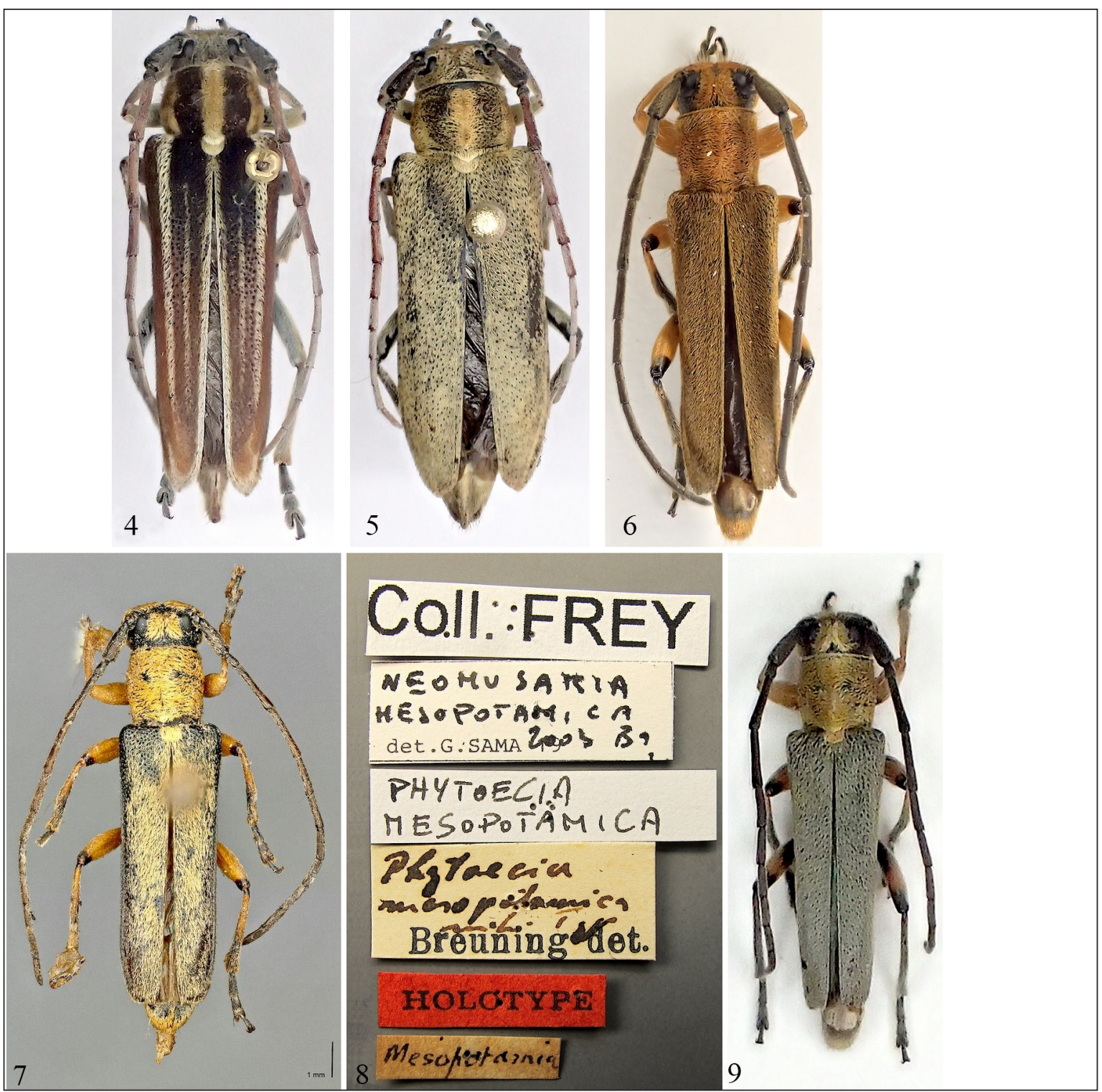

Figure 4. Pygoptosia darzerkensis Rapuzzi n. sp. Holotype male. Figure 5. Pygoptosia darzerkensis Rapuzzi n. sp. Paratype female, Mardin, Nur Mahallesi (Darzerke). Figure 6. Phytoecia (s. str.) aenigmatica Sama, Rapuzzi et Rejzek, 2007, male, Artuklu, Mardin, Hamzabey Mahallesi (Vadi Birkit1lcemel). Figure 7. Phytoecia (Neomusaria) mesopotamica Breuning, 1948. Holotype male, Coll. Frey, National Museum Basel, Switzerland. Figure 8. Phytoecia (Neomusaria) mesopotamica Breuning, 1948. Labels, Holotype male, Coll. Frey, National Museum Basel, Switzerland. Figure 9. Phytoecia (Neomusaria) mesopotamica ssp. barbarae Rapuzzi n. ssp. Holotype male. 
REMARKS. This new subspecies is easy to distinguish from the nominal one by the darker color of the legs; the middle tibiae orange only on the basal third (completely orange in the nominotypical subspecies); the hind tibiae spotted with orange only near the apex (orange on more than the first half in the nominotypical subspecies). The shape of the pronotum is different, as in $P$. (N.) mesopotamica barbarae n. ssp. it is shorter and wider than in the nominal form. The elytral apex is more evidently truncate in the new subspecies.

Phytoecia (Neomusaria) mesopotamica Breuning, 1948 was described from Ras Elain (NE Syria) (type specimen Figs. 7, 8) and recently discovered also in Iran (Kamyaran area, Khordestan) (Sama et al., 2006). It is interesting to note how many species from Iran (mainly from Zagros mountains and Khordestan) were recently discovered in Mardin area, showing a similarity between these two regions of the Middle East.

Phytoecia (Opsilia) Mulsant, 1862

Opsilia Mulsant, 1862. Type species: Leptura coerulescens Scopoli, 1763 = Saperda virescens Fabricius, 1781 (designed by Villiers, 1978).

Phytoecia (Opsilia) coerulescens (Scopoli, 1763) Leptura coerulescens Scopoli, 1763.Type locality: "Carniola" (Slovenia).

RANGe. E: AL AU BE BH BU ?BY CH CR CT CZ FR GE GR HU IT LA LS LT LU MC MD NL PL PT RO SK SL SP ST SZ TR UK YU N: AG MO TU A: AB AR GG IN IQ IS JO KI KZ LE NE TD TR SY UZ WS (Danilevsky, 2019).

MARDIN. Mardin (Tezcan et al., 2020b: 167); Hop Geçidi (Çinaralti vill.) $15 \mathrm{~km}$ NE Mardin, 3723N 4051E, 16.V.2001 (Coll. Martin REJZEK); Artuklu, Nur Mahallesi (Darzerke), 900 m., 30.V.2017, on Echium italicum (Boraginaceae), M. Geçit leg. (MGPA).

Phytoecia (Paracoptosia) Danilevsky, 2017

Phytoecia subg. Paracoptosia Danilevsky, 2017. Type species: Saperda compacta Ménétries, 1832.

Phytoecia (Paracoptosia) bithynensis Ganglbauer, 1883

Phytoecia bithynensis Ganglbauer, 1884. Type locality: Kleinasien, Brussa (Turkey).
RANGE. A: TR (Danilevsky, 2019).

MARDIN. Hop Geçidi (Çinaralti vill.) $15 \mathrm{~km} \mathrm{NE}$ Mardin, 3723N 4051E, 16.V.2001 S. Kadlec leg. (NMPC).

Phytoecia (Paracoptosia) compacta Ménétriés, 1832

Phytoecia compacta Ménétriés, 1832. Type locality: Baku (Azerbaijan).

Range. A: AB AR GG IN TR (Danilevsky, 2019).

MARDIN. Ömerli, 12.VI.1972 (Tezcan et al., 2020b: 151)

Phytoecia (Paracoptosia) minuta Pic, 1891

Phytoecia (Coptosia) minuta Pic, 1891. Type locality: Mount Amanus (Turkey).

Coptosia mardinensis Pic, 1901: 13.

RANGE. A: TR (Danilevsky, 2019).

MARDIN. Mardin (typ.locality C. mardinensis Pic, 1901); Mardin (Özdikmen, 2013a: 90).

Pilemia Fairmaire, 1868

Pilemia Fairmaire, 1868.

Type species: Phytoecia tigrina Mulsant, 1851 (designed by Breuning, 1951).

Pilemia (Pilemia) breverufonotata (Pic, 1952)

Phytoecia (Pilemia) tigrina v. breverufonotata Pic, 1952. Type locality: Brousse, Asie Minor (Turkey).

RANGE. A: TR (Danilevsky, 2019).

MARDIN. Hop Geçidi (Çinaralti vill.) $15 \mathrm{~km} \mathrm{NE}$ Mardin, 3723N 4051E, 16.V.2001 (GSCC).

Pilemia (Pilemia) griseomaculata Pic, 1891

Pilemia tigrina v. griseomaculata Pic, 1891. Type locality: Akbes (Turkey).

RANGE. A: SY TR (Danilevsky, 2019).

MARDIN. $10 \mathrm{~km}$ E Miadat, 800 m., 37² $22^{\prime} \mathrm{N}$

$42^{\circ} 09^{\prime}$ E, 10.V.2007, leg. Hajdaj (NMPC).

Pilemia (Pseudopilemia) Kasatkin, 2018

Phytoecia subgen. Pseudopilemia Kasatkin, 2018. 
Type species: Saperda hirsutula Frölich, 1793 (Original designation).

Pilemia (Pseudopilemia) hirsutula hirsutula (Frölich, 1793)

Saperda hirsutula Frölich, 1793. Type locality: Austria.

RANGE. E: AL BH BU CR GR HU KZ MC MD ME RO SK SL ST UK YU A: AB AR GG IN IS JO LE KZ SY TR WS (Danilevsky, 2019).

MARDIN. Sultan meadow, Mardin centre, 1080 m., 16.V.2017, on Eremostachys lacinata, M. Geçit leg. (MGPA).

Pygoptosia Reitter, 1895

Pygoptosia Reitter, 1895. Type species: Phytoecia speciosa Frivaldsky, 1884 (by monotypy).

Pygoptosia darzerkensis Rapuzzi n. sp. (Figs. 4, 5) https://zoobank.org:act:0241AEE1-4547-470793C0-D4D1DEE731AD

TYPE SERIES. Holotype $\delta$ : Turkey, Mardin, Nur Mahallesi (Darzerke), 940 m., on Centaurea behen, 28.IV.2016, M. Geçit leg. (PRCU). Paratypes: 1 q with same data as the holotype (PRCU); $2 \hat{\jmath} \hat{0}$ and $2 ㅇ$, same data as the holotype, 08.V.2017, on Centaurea behen, M. Geçit \& S. Tusun leg. M. Geçit leg. (MGPA).

DESCRIPTION OF THE HOLOTYPE MALE. Length $20.5 \mathrm{~mm}$., humeral width $5.5 \mathrm{~mm}$. Body mostly reddish, covered by white and yellow pubescence. Head pitchy-brown, completely covered by dense yellowish pubescence. Lateral margins of the mandibles covered by the same pubescence. Frons, labium and genae with several very long, erect, yellowish setae. Frons square, with a small furrow in the middle of the apex. Antennal tubercles prominent, surrounded by several large and deep punctures; which are visible over the apex of the head. Antennae long, exceeding the elytral apex by the last segment, reddish-brown except for the scape and pedicellum which are black. Pubescence of antennae silvery, denser toward the apical segments. Pronotum slightly wider than long, with rounded sides, pitchy-brown colored, with three longitudinal bands of yellowish pubescence, one on each side and one in the middle. Between these stripes, the surface is covered by a rather sparse, dark-brown pubescence. Pronotal surface covered with many long, erect, golden setae. Pronotal surface rather shiny, with a few bigger punctures mixed with several smaller ones. Frontal margin of the pronotum straight, basal margin strongly sinuate. The discal area of pronotum with a long medial carina, covered by dense and semi-erect yellowish pubescence, and two prominent shining callosities. The basal end of the yellowish stripe on the middle of the pronotum is projected towards the scutellum with a lighter yellowish spot that also covers part of the scutellum. Scutellum elongate, completely covered by strong dense, recumbent yellowish pubescence.

Elytra long, regularly narrowed towards the apex, with apex obtusely acuminate. Elytral punctation with sparse, regular, large punctures, sparser and smaller toward the apex. The basal microsculpture is comprised of small dense punctures which give the elytra a matte aspect. Basal third of the elytral surface black, except lateral portions which are pitchy-brown as the rest of the elytra. The elytral pattern consists of three main longitudinal white stripes, the lateral ones running straight from the humeri, progressively narrowing until ending before the elytral apex; the central white band runs along the elytral suture starting from the scutellum, and continues along the elytral apex; two additional shorter stripes are present between the central and the two lateral bands. Elytral pubescence recumbent, without any erect bristles. Legs rather long, strong, entirely covered by mixed whitish and yellowish pubescence. Tarsi black with silver-white pubescence.

VARIABILITY. The female differs from the male by its stouter body shape. The elytral color is homogeneous, made by yellowish pubescence. The pronotum has three longitudinal yellowish stripes, mixed with yellowish, less dense pubescence.

Biology. All the known specimens, including mating pairs, were collected on leaves of Centaurea behen (Asteraceae), that is very likely the hostplant, and the same host-plant of the closely related species Pygoptosia eugeniae.

Remarks. This new species is similar to Pygoptosia eugeniae (Ganglbauer, 1884), based on the structure and the general shape of the body. It is easily distinguished by the two shining callosities on the pronotum in the male which are missing in $P$. 
eugeniae. The erect pubescence on the pronotum is longer and denser in the new species. The pronotum is wider and distinctly rounded laterally in both sexes, longer and more straight in P. eugeniae. The shape of the last abdominal segment is completly different in both sexes. In the male it is evidently straighter, with the carina very prominent, much more than in P. eugeniae males, the pubescence on the last abdominal segment is sparser and golden, mixed with black setae, instead of completely golden. In the female the last segment is stouter, with the apex acuminate instead of being rounded. The middle carina is very prominent as well, much more than in P. eugeniae females. In both sexes the base of the pronotum is covered by dense and strong golden pubescence, in the basal mid part of the pronotum this pubescence is denser and partially covers the base of the scutellum; in P. eugeniae this pubescence is sparser, not covering the base of the scutellum.

Pygoptosia eugeniae (Ganglbauer, 1884) was recentely recorded for the Turkish fauna (Tezcan et al., 2020b: 150) on the base of two specimens preserved in Lodos collection (housed in Lodos Entomological Museum, Ege University, Izmir, Turkey): Siirt: 11.V.1972, det. Holzschuh, as Phytoecia eugeniae; Şırnak: Beytüșșebap, 15.VI.1976, Fraxinus sp., det. Holzschuh, as Phytoecia eugeniae. It will be necessary to study these speciemns to state the correct identification. In fact it is very likely due to the very close localities that these records must be refered to the new species.

Pygoptosia speciosa (Frivaldszky, 1884)

Phytoecia speciosa Frivaldszky, 1884. Type locality: Diarbekir (Turkey).

RANGe. A: IN LE SY TR (Danilevsky, 2019).

Mardin. Hop Geçidi, Çinaralti vill., 16.V.2001 (Rejzek et al., 2003: 179; Özdikmen, 2013a: 90); Hop Geçidi (Çinaralti vill.), 15 km NE. Mardin, $37^{\circ} 23^{\prime} \mathrm{N} 40^{\circ} 51^{\prime} \mathrm{E}, 16 . \mathrm{V} .2001$, M. Rejzek leg. (GSCC); Artuklu, Hamzabey Mahallesi (Vadi Birkit1lcemel), on Serratula cerinthifolia, 970 m., 16.V.2017, M. Geçit leg. (MGPA).

Semiangusta Pic, 1892

Phytoecia (Semiangusta) Pic, 1892. Type species: Conizonia Delagrangei Pic, 1891 (designed by Pic, 1952).
Semiangusta delagrangei Pic, 1891

Conizonia delagrangei Pic, 1891. Type locality: Akbes (Turkey).

RANGE. A: TR (Danilevsky, 2019).

Mardin. Dereyani env., 27.V.2011, D. Sanč leg. (PRCU); Hamzabey Mahallesi (Vadi Birkit1lcemel), 976 m., on Cenaturea behen, 21.V.2016; M. Geçit leg.; idem, 26.V.2017; idem 13.V.2018 (MGPA); Çaglar vill., 37²2'59”N 4042'06", 997 m., 13.V.2018, on Centaurea behen, P. Rapuzzi leg. (PRCU).

SAPERDINI Mulsant, 1839

Saperdaires Mulsant, 1839.

Type genus: Saperda Fabricius, 1775.

Saperda Fabricius, 1775

Saperda Fabricius, 1775. Type species: Cerambyx scalaris Linnaeus, 1758.

Saperda (Compsidia) Mulsant, 1839

Compsidia Mulsant, 1839. Type species: Cerambyx populneus Linnaeus, 1758.

Saperda (Compsidia) quercus ocellata Abeille, 1895

Saperda (Compsidia) ocellata Abeille de Perrin, 1895. Type locality: Akbes (Turkey).

RANGE. A: IS JO SY TR (Danilevsky, 2019).

MARDIN. Hop Gec., 2300 m., N4000’ E40³2', 8.VI.2001; Akgevit, 11.V.1984, leg. Wellschmied (GSCC).

\section{ACKNOWLEDGEMENTS}

We are thankful to the General Directorate of Nature Conservation and National Parks (DKMP) for research permissions issued with nr. 72784983488.04-58779 (March 10, 2017), namely for "Determination of Coleoptera (Cerambycidae) fauna of Mardin province, and analysis of species in terms of vector". We are thankful to the World Biodiversity Association (WBA) for the small grant provided in support to our expeditions. We are also grateful to Max Barclay (National Museum, London, Great Britain), Cristoph Germann (Conserva- 
tor entomology of the Naturhistorisches Museum Basel, Switzerland), Eva Sprecher (Naturhistorisches Museum Basel, Switzerland), Jiri Hajek (National Museum, Prague, Czech Republic) and to Mauro Malmusi (Modena, Italy).

\section{REFERENCES}

Adlbauer K., 1992. Zur Faunistik und Taxonomie der Bockkäferfauna der Türkei II. Entomofauna, Zeitschrift für Entomologie, 13 (30): 485-512.

Avgın S.S., Dertli İ. \& Barševskis A., 2014. A review of Turkish saproxylic beetles from the European Red List. Annales de la Société entomologique de France (N.S.). International Journal of Entomology; 50: 501-538. https://doi.org/10.1080/00379271.2014.896099

Braun W., 1978. Die Dorcadienausbeute der Forschungreisen von W. Heinz 1963-1977. Nachrichtenblatt der Bayerischen Entomologen, 27: 101-116.

Breuning S., 1962. Revision der Dorcadionini (Col. Ceramb.). Abhandlungen und Berichte aus dem staatlichen Museum für Tierkunde in Dresden 27: $1-666$

Danilevsky M.L., 2011. New subspecies of Stenurella bifasciata (Müller, 1776) (Coleoptera, Cerambycidae from South West Turkey. Munis Entomology \& Zoology, 6: 1-5.

Danilevsky M.L., 2012. Additions and corrections to the new Catalogue of palaearctic Cerambycidae (Coleoptera) edited by I. Löbl and A. Smetana, 2010. Part. III. Munis Entomology \& Zoology, 7: 109-173.

Danilevsky M.L., 2019. http://www.cerambycidae.net

Fuchs E. \& Breuning S., 1971. Die Cerambycidae Ausbeute der Anatolien Expeditionen 1966-67 des Naturhistorischen Museums, Wien. Annalen des Naturhistorischen Museums in Wien, 75: 435-439.

Heyden L., 1894. Ueber Meloe Olivieri Chevrolat und sechs neue Longicornen aus Klein-Asien. Deutche Entomologische Zeitschrift, 1894: 85-90.

Holzschuh C., 1975. Zur Synonymie palaearktischer Cerambycidae I. (Col.). Koleopterologische Rundschau, 52: 101-104.

Holzschuh C., 1980. Revision einer Cerambyciden Ausbeute des Naturhistorischen Museums Wien (Coleoptera). Annalen des Naturhistorischen Museums in Wien, 83: 573-574.

Löbl I. \& Smetana A. (Eds.), 2010. Catalogue of Paleartic Coleoptera. Volume 6. Chrysomeloidea. Apollo Books, Stenstrup, 924 pp.

Lodos N., 1998. Entomology of Turkey VI (General, Aplied and Faunistic). Ege Ü. Ziraat Fak. Yayınları No: 529, E. Ü. Faculty of Agriculture Press, İzmir, $300 \mathrm{pp}$.
Kaplan C., 2013. Güneydogu Anadolu Bölgesi meyve agaçlarında zararlı Osphranteria coerulescens Redtenbacher, 1850 (Coleoptera: Cerambycidae)'in yayılışı, konukçuları, zarar Gekli ve bazı biyolojik özellikleri [Determination of distribution, hosts, damage and some biologic properties of Osphranteria coerulescens Redtenbacher, 1850 (Coleoptera: Cerambycidae) harmful on fruit trees in South East Anatolian Region]. Bitki koruma bülteni (Plant protection bulletin), 53: 1-6.

Önalp B., 1988. Taxonomic researches on Agapanthia Serville, 1835 species (Coleoptera, Cerambycidae: Lamiinae). Eğitim Fakültesi Dergisi, 3: 257-295.

Onalp B., 1989. Taxonomic researches on Agapanthia Serville, 1835 species (Coleoptera, Cerambycidae: Lamiinae) I.H.U: Eğtim Fakuiltesi Dergisi, 4: 197-234.

Önalp B., 1990. Systematic researches on Dorcadion Dalman, 1817 species in Turkey (Coleoptera, Cerambycidae: Lamiinae). Eğitim Fakültesi Dergisi, 5: 57-102.

Önalp B., 1991. Türkiye'de Dorcadion Dalman, 1817 (Cerambycidae: Lamiinae) sistematik araştirmalar. Egitim Fakuiltesi Dergisi, 6: 191-227.

Özdikmen H., 2008. The Longicorn Beetles of Turkey (Coleoptera, Cerambycidae). Part III - Aegean Region. Munis Entomology \& Zoology, 3: 355-436.

Özdikmen H., 2010. The Turkish Dorcadiini with zoogeographical remarks (Coleoptera: Cerambycidae: Lamiinae). Munis Entomology \& Zoology, 5: 380-498.

Özdikmen H., 2013a. Turkish Agapanthiini Mulsant, 1839 with identification keys (Coleoptera: Lamiinae). Munis Entomology \& Zoology, 8: 9-40.

Özdikmen H., 2013a. The Longicorn Beetles of Turkey (Coleoptera: Cerambycidae) Part V - South-Eastern Anatolian Region. Munis Entomology \& Zoology, 8: 67-123.

Özdikmen H., 2013b. Turkish Agapanthiini Mulsant, 1839 with identification keys (Coleoptera: Lamiinae). Munis Entomology \& Zoology, 8: 9-40.

Özdikmen H., 2016a. Two new species group taxa of Cortodera (Coleoptera: Cerambycidae: Lepturinae) from Turkey with updated species group list. Munis Entomology \& Zoology, 11: 4-17.

Özdikmen H., 2016b. Dorcadionini of Turkey (Coleoptera: Cerambycidae), Journal of Natural History, 50 (37-38): 2399-2475.

Özdikmen H., 2017. Updated species group taxa of Phytoecia (Phytoecia) Dejean in Turkey with a new status (Coleoptera: Cerambycidae: Lamiinae). Munis Entomology \& Zoology, 12: 110-119.

Özdikmen H. \& Cihan N., 2016. Updated List of Chlorophorus Chevrolat, 1863 (Coleoptera: Cerambycidae: Cerambycinae) Species from Turkey, with 
two new restorations. Pakistan Journal Zoology, 48: 356-376.

Özdikmen H. \& Cihan Tüzün N., 2018. Distribution of Calchaenesthes species in Mediterranean Region. Munis Entomology \& Zoology, 13: 106-116.

Özdikmen H. \& Özdikmen G., 2016. Updated world species list of the subgenus Phytoecia (Neomusaria) Plavilstshikov, 1928 with two new species from Turkey (Cerambycidae: Lamiinae). Munis Entomology \& Zoology, 11: 492-500.

Özdikmen H. \& Turgut S., 2010. An overview on the WPaleartic subgenus Phytoecia (Helladia) Fairmaire, 1864 with a new subspecies Phytoecia (Helladia) humeralis caneri ssp. n. from Turkey (Coleoptera: Cerambycidae: Lamiinae). Munis Entomology \& Zoology, 5: 317-343.

Plavilstshikov N.N., 1931. Bestimmungs-Tabellen der europäischen Coleopteren, Troppau, BTEC: 1-102 pp. Cerambycidae I. Teil Cerambycinae: Disteniini, Cerambycini 1 (Prothaxina, Spondylina, Asemina, Saphanina, Achrysoina, Oemina, Cerambycina).

Rapuzzi P. \& Sama G., 2013. Revision of the Purpuricenus interscapillatus species - group and allied taxa (Coleoptera, Cerambycidae). Fragmenta entomologica, 45: 143-171. https://doi.org/10.4081/fe.2013.22

Rejzek M., Sama G., Alziar G. \& Sadlo J., 2003. Host plants of longhorn beetles (Coleoptera: Cerambycidae) from the Balkan Peninsula, Asia Minor, and Iran (Part II). Biocosme Mésogéen, 19: 161-189.

Sama G., Rapuzzi P. \& Özdikmen H., 2012. Preliminary report of the entomological surveys $(2010,2011)$ of G. Sama and P. Rapuzzi to Turkey (Coleoptera: Cerambycidae). Munis Entomology \& Zoology, 7: 22-45.

Sama G., Rapuzzi P. \& Rejzek M., 2007. New or interesting Phytoeciini from the Middle East, especially from Iran (Coleoptera: Cerambycidae). Folia Heyrovskyana, 14: 163-179.

Tezcan S., Karsavuran Y., Pehlivan E. \& Özdikmen H., 2020a. Catalogue of Longhorned Beetles of LEMT (Coleoptera: Cerambycidae) Part I: Prioninae, Lepturinae, Aseminae, Saphaninae, Spondylidinae, Cerambycinae and Stenopterinae. Munis Entomology \& Zoology, 15: 39-65.

Tezcan S., Karsavuran Y., Pehlivan E. \& Özdikmen H., 2020b. Catalogue of Longhorned Beetles of LEMT (Lodos Entomological Museum, Turkey) (Coleoptera: Cerambycidae) Part II: Lamiinae and Dorcadioninae. Munis Entomology \& Zoology, 15: 145-170.

Tezcan S. \& Rejzek M., 2002. Longhorn beetles (Coleoptera: Cerambycidae) recorded in cherry orchards in western Turkey. Zoology in Middle East, 27: 91-100. 